\title{
Papillary, Follicular, Hurthle Cell, Poorly Differentiated, and Anaplastic Thyroid Carcinoma Pathologic Regional Lymph Nodes TNM Finding v8
}

National Cancer Institute

\section{Source}

National Cancer Institute. Papillary, Follicular, Hurthle Cell, Poorly Differentiated, and

Anaplastic Thyroid Carcinoma Pathologic Regional Lymph Nodes TNM Finding v8. NCI

Thesaurus. Code C140925.

A pathologic finding about one or more characteristics of papillary, follicular, Hurthle cell, poorly differentiated, and anaplastic thyroid carcinoma, following the rules of the TNM AJCC v8 classification system as they pertain to staging of regional lymph nodes. 